\title{
Gifted Children's Representations of Learner Identities
}

\author{
Marion Porath \\ The University of British Columbia \\ Judy Lupart \\ University of Alberta
}

\begin{abstract}
Elementary and secondary students identified as gifted produced representations of themselves as readers, writers, and mathematicians and were interviewed about what they chose to represent. Interviews indicated a developmental progression in the way academic learning is understood, a progression that also was evident in their representations. Action-based understanding of academic learning in early childhood progresses to increasingly complex integration of mental activity and knowledge of self-as-learner with descriptions of learning activities in middle childhood. Adolescence is marked by views of learning as transformative and emergent recognition of the nature of knowledge as important in learning. The representations showed similar developmental characteristics, but also offered complementary, creative views of the students' learning identities.
\end{abstract}

Even though the past several decades have been highly productive in generating new insights concerning teaching and learning processes (Bransford, Brown, \& Cocking, 2000), children's perceptions of learning are noticeably absent in educational research. Similarly, educational practice typically disregards learners' perspectives on knowledge and their understanding of their capacity for learning (Bruner, 1996). Moreover, adult conceptions of children's points of view and educational needs are often erroneous (Waksler, 1991). Children's mental representations are a powerful tool for understanding their development, yet the approach is underused in research and education (Bruner, 1996; Dweck \& London, 2004). Children's conceptualizations of their own minds and identities as learners may be exceptionally rich contributors to our understanding of their abilities and motivations to learn. The classroom is a complex setting. Students need to understand academic expectations and their own ways of learning in order to be successful, and teachers need to understand students' perspectives in order to support them to be successful. These needs increase this complexity. 
In particular, it is imperative that we know how children with ability profiles that are significantly developmentally advanced, but at the same time, highly variable, understand their own needs in relation to schooling. Familiar norms do not apply to these children, and significant adaptations need to be made in the academic and social aspects of their schooling (Robinson, Zigler, \& Gallagher, 2000). Growth rates and degree of asynchrony in their academic developmental profiles are significantly different from those of typically developing children (Keating, 1991; Liddle \& Porath, 2002; Lubinski \& Benbow, 2000; Matthews, 1997; Robinson et al., 2000; Yewchuk \& Lupart, 2000). These particular learning patterns present significant challenges to school adjustment and achievement of potential in large part because they are often either misunderstood or not understood at all by schools (Keating, 1991).

Children are thinkers (Bruner, 1996) with competent and legitimate ways of making sense of the world. Learning is optimized when the legitimacy of these ways of knowing is honoured (Katz, 1998; Krechevsky \& Seidel, 1998). This constructivist philosophy and practice underpins the "Reggio approach" to early childhood education that is based on the renowned early schooling in Reggio Emilia, Italy (Project Zero \& Reggio Children, 2001). This approach takes children's perspectives as the starting point for learning; offers children diverse options to represent their knowledge; and documents learning processes in detail. The approach has significant potential for contributing to our knowledge of gifted learners' perspectives on their abilities and identities as learners and to education that supports their optimal development (see Lai's paper in this issue).

Children need to have access to a number of forms of representation of knowledge (Project Zero \& Reggio Children, 2001); this access may be particularly important in understanding their conceptions of the world of learning and academic identity, a world in which narrative knowledge predominates as the way of making meaning (Bruner, 1986; Gallas, 1994). Narrative is defined broadly to include both verbal and nonverbal ways of making meaning (Gallas, 1994; Hanna, 2008). Nonverbal cognition has been overlooked in education (Hanna, 2008) despite a growing body of literature that demonstrates how the arts can bring new ways of understanding to students, teachers, and researchers (Woo, 2008). Expansion of the ways in which children can represent their knowledge provides them with a repertoire of "tools for thinking" that are "inherently transdisciplinary” (Root-Bernstein \& Root-Bernstein, 2005, p. 194; see also Fogel's and Ngara's papers, this issue).

\section{Method}

As part of a larger study investigating gifted children's and adolescents' perspectives on learning; how they understand their patterns of development in reading, writing, and mathematics; and their perspectives on their own and others' roles and responsibilities in school (Porath \& Lupart, 2007), students were asked to represent their perceptions of themselves as readers, writers, mathematicians, and other identities of their choice in ways of their own choosing. A page with written prompts and accompanying graphics as 'idea starters' was given to the students (see Appendix) and discussed before they began their representations. The focus of the project was on literacy (reading, writing) and numeracy; the option to include another identity was added in response to an adolescent's comment that a focus on academic subjects "reinforced the stereotype" of gifted students. His insight that "we're more than that" prompted the addition of an option to include another identity as part of the task. 
Eighty-one students from grades 1 through 12 participated in the larger study that took place in two large western Canadian cities. The students were all identified as gifted using a combination of teacher nomination, superior academic achievement, and/or superior intelligence or cognitive ability test scores. They attended a variety of programs for gifted learners, including segregated classes and pullout programs. Forty-five students (24 males, 21 females) completed the representation task (2 in Grade 1; 3 in Grade 3; 1 in Grade 4; 11 in Grade 5; 5 in Grade 6;12 in Grade 7; 6 in Grade 10; and 5 in Grade 12).

Students were first engaged in conversations about their identities as learners and other learning identities (i.e., other ways in which they demonstrate what they have achieved and areas in which they feel competent, not necessarily school-related; Perry, 2003) and possible ways of representing their perceptions of themselves. They then were given time to construct their representations. In some cases, students were given class time to work on their representations; in other cases, they completed them individually. Following completion of the task, students were individually interviewed about their motivations for how they chose to represent themselves. In a few cases, students e-mailed their representations to the researcher and included a written rationale for why they responded as they did. Thirty-nine students completed a follow-up interview or e-mail.

\section{Results}

Representations included drawings, collages, diagrams, a mobile, poems, and music. The representations and interviews were examined for apparent themes and developmental characteristics.

\section{Interviews}

Initial examination of the interview data indicated thematic and developmental similarities to the definitions of learning and statements about the personal meaning of reading, writing, and mathematics collected in the larger study (Porath, 2006; Porath \& Lupart, 2007). Children offered these definitions and statements in response to the following questions/prompts: "What does learning mean? What is happening when you are learning? Where does learning come from?" (Bickerton, 1994) and "Describe what reading/writing/math means to you. What is happening when you are reading/writing/doing math?" (Porath \& Lupart, 2007). Thus, interview data were coded using the categories previously identified to capture the developmental progression in children's understanding of learning in general and academic subjects specifically (Table 1). These coding guidelines were the result of an iterative process in which data were examined in light of Case's (1992) neo-Piagetian theory of development; prototypical characteristics of stages in child and adolescent development defined; and children's best responses assigned to a level of development. The process used was a "constructivist revision of grounded theory" (Henwood \& Pidgeon, 2003, p. 134); the data guided interpretation within the conceptual framework of developmental theory using the steps of open coding, constant comparison, and theoretical integration (Henwood \& Pidgeon, 2003).

The categories developed in the process described above captured the increasingly sophisticated progression in understanding learning and academic tasks from simple, action-based explanations in the first years of school through recognition of the role of mental activity and 
Table 1

Development of Children's Understandings of Learner Identities from Early Childhood to Adolescence

\begin{tabular}{|c|c|c|c|c|c|}
\hline & $\begin{array}{l}\text { Understanding of self } \\
\text { as learner }\end{array}$ & $\begin{array}{l}\text { Understanding of self } \\
\text { as reader }\end{array}$ & $\begin{array}{l}\text { Understanding of self } \\
\text { as writer }\end{array}$ & $\begin{array}{l}\text { Understanding of self } \\
\text { as mathematician }\end{array}$ & $\begin{array}{l}\text { Representations of self } \\
\text { as reader, writer, and } \\
\text { mathematician }\end{array}$ \\
\hline \multirow[t]{2}{*}{$\begin{array}{l}\text { Early } \\
\text { childhood }^{\mathrm{a}}\end{array}$} & \multirow[t]{2}{*}{$\begin{array}{l}\text { Simple and action- } \\
\text { based } \\
\text { You have to learn } \\
\text { stuff. }\end{array}$} & $\begin{array}{l}\text { Simple and action-based; simple } \\
\text { descriptions of things associated } \\
\text { with reading. } \\
\text { The alphabet. Read books and } \\
\text { stuff. }\end{array}$ & $\begin{array}{l}\text { Simple and action-based; } \\
\text { simple descriptions of things } \\
\text { associated with writing. } \\
\text { Pencils and erasers }\end{array}$ & $\begin{array}{l}\text { Simple and action-based descrip- } \\
\text { tions of math; simple descriptions of } \\
\text { things associated with math } \\
\text { Numbers, calculators } \\
\text { It's when you add things up. }\end{array}$ & $\begin{array}{l}\text { So this must be you as a } \\
\text { writer? Yeh. Because he } \\
\text { has the pencil and the } \\
\text { paper on the table. And } \\
\text { that's the reader because } \\
\text { that's a book. }\end{array}$ \\
\hline & & $\begin{array}{l}\text { Descriptions of reading "actions" } \\
\text { or "events" are combined with } \\
\text { recognition of how information is } \\
\text { processed. } \\
\text { Beginning use of verbs associated } \\
\text { with using minds/brains to read } \\
\text { (figure out, process) } \\
\text { You figure out the words, process } \\
\text { them. } \\
\text { Looking at letters and sounding it } \\
\text { out in your head. }\end{array}$ & $\begin{array}{l}\text { Descriptions of writing "ac- } \\
\text { tions" or "events" are } \\
\text { combined with recognition of } \\
\text { how information is processed } \\
\text { or writing skills acquired. } \\
\text { Talk about how they can be- } \\
\text { come better writers (e.g., get } \\
\text { better by practice, better spel- } \\
\text { ling). } \\
\text { It means concentrate. You } \\
\text { gotta look and focus on the } \\
\text { words. } \\
\text { You're using your brain to } \\
\text { move your hand and use your } \\
\text { brain to think what you're } \\
\text { going to write and remember } \\
\text { all the letters, how to spell } \\
\text { them. }\end{array}$ & $\begin{array}{l}\text { Descriptions of math "actions" or } \\
\text { "events" are combined with recogni- } \\
\text { tion of how information is processed } \\
\text { or math skills acquired. } \\
\text { Talk about how they can become } \\
\text { better at math (e.g., you practice; } \\
\text { drill facts; learn how to calculate). } \\
\text { Your brain, it's getting a lot of ideas } \\
\text { and numbers. } \\
\text { Maybe multiplicating ... and dividing } \\
\text { and subtracting and adding. Learn- } \\
\text { ing, learning new things. }\end{array}$ & \\
\hline $\begin{array}{l}\text { Middle } \\
\text { childhood } 1 \\
\text { (Age } 8 \text {-10) }\end{array}$ & $\begin{array}{l}\text { Learning actions are } \\
\text { coordinated with men- } \\
\text { tal activity (e.g., } \\
\text { thinking, remember- } \\
\text { ing). } \\
\text { Emergent recognition } \\
\text { of the different ways } \\
\text { one can learn } \\
\text { Recognition of the role } \\
\text { of understanding in } \\
\text { learning } \\
\text { To do ...no, not to do } \\
\text { but to think about what } \\
\text { something means. }\end{array}$ & $\begin{array}{l}\text { Descriptions of reading "actions" } \\
\text { or "events" are combined with } \\
\text { descriptions of how skills in read- } \\
\text { ing are acquired and how } \\
\text { knowledge is acquired through } \\
\text { reading. } \\
\text { Reading is like ... you ... there's a } \\
\text { story and then when you read it, } \\
\text { you sort of absorb the story into } \\
\text { your head and then you can re- } \\
\text { member it for awhile and then you } \\
\text { can share it to other friends and } \\
\text { then you can make connections to } \\
\text { other books in that series. }\end{array}$ & $\begin{array}{l}\text { Descriptions of writing "ac- } \\
\text { tions" or "events" are } \\
\text { combined with descriptions of } \\
\text { how skills in writing are ac- } \\
\text { quired and how knowledge is } \\
\text { disseminated through writing. } \\
\text { Writing down your thinking- } \\
\text { what you have stuck up in } \\
\text { your head. }\end{array}$ & $\begin{array}{l}\text { Descriptions of math "actions" or } \\
\text { "events" are combined with descrip- } \\
\text { tions of how math skills (facts) and } \\
\text { knowledge are acquired. } \\
\text { Math means to me like some num- } \\
\text { bers and some like signs and then } \\
\text { it's a way to figure out things. Like } \\
\text { subtraction is a way to figure out } \\
\text { how much change you should get. } \\
\text { Addition is to figure out maybe like } \\
\text { how much say you bought some } \\
\text { things and you're adding the prices } \\
\text { together to see if you have enough } \\
\text { money to buy it like and then same } \\
\text { kind of like on times tables and the } \\
\text { division. }\end{array}$ & $\begin{array}{l}\text { For the reader one: I think } \\
\text { I am a good reader so I } \\
\text { will read to little children in } \\
\text { schools. } \\
\text { Well I thought that math } \\
\text { makes you think and it can } \\
\text { be kind of hard sometimes } \\
\text { and there's lots of different } \\
\text { kinds of math. }\end{array}$ \\
\hline
\end{tabular}

Note. Children's responses are in italics.

${ }^{a}$ Early childhood responses are divided into early primary (age 6) and late primary (age 7) for conceptions of self as reader, writer, and mathematician. 


\section{Table 1 Continued}

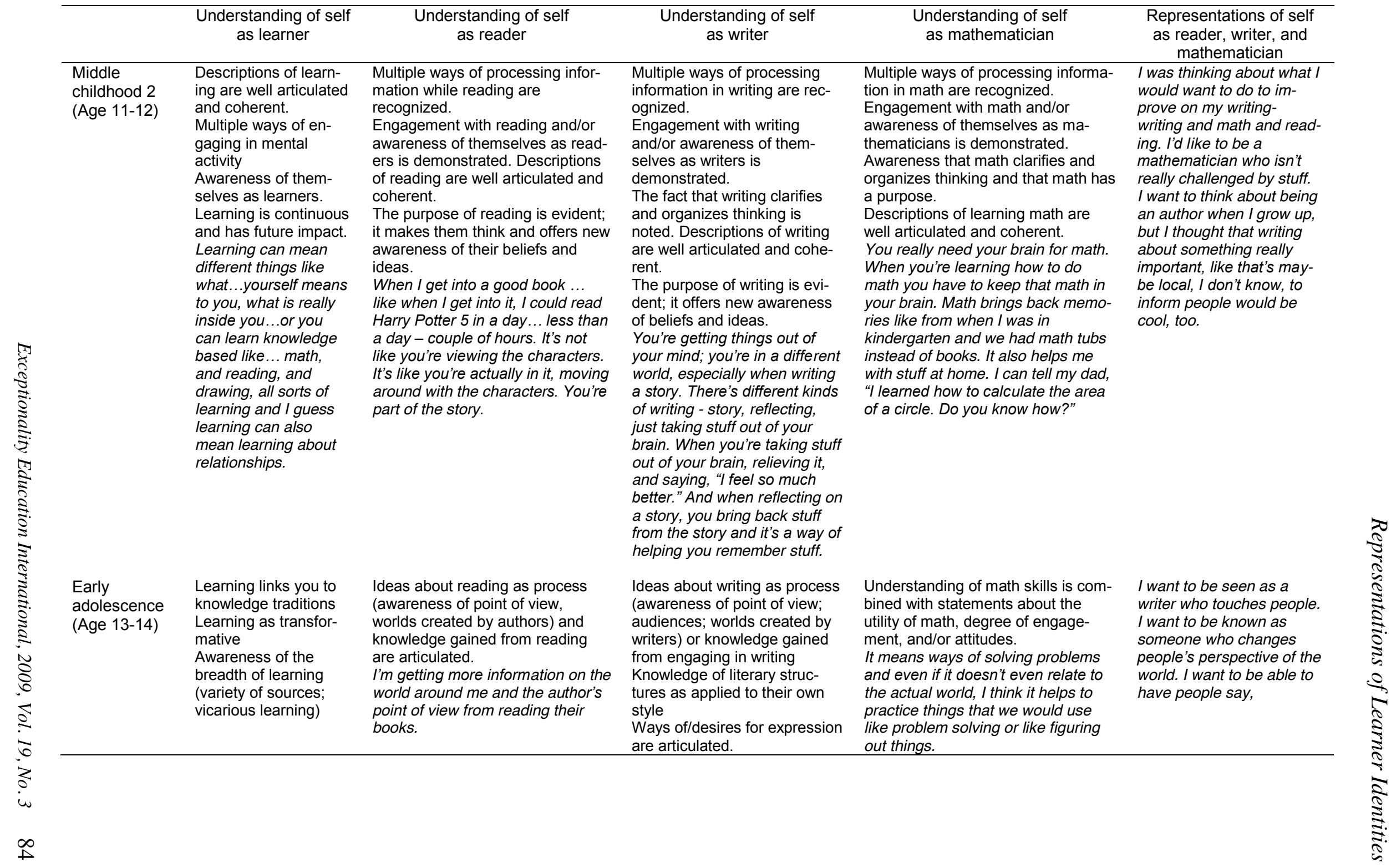




\begin{tabular}{|c|c|c|c|c|c|}
\hline & $\begin{array}{l}\text { Understanding of self } \\
\text { as learner }\end{array}$ & $\begin{array}{l}\text { Understanding of self as } \\
\text { reader }\end{array}$ & $\begin{array}{c}\text { Understanding of self as } \\
\text { writer }\end{array}$ & $\begin{array}{l}\text { Understanding of self as } \\
\text { mathematician }\end{array}$ & $\begin{array}{l}\text { Representations of self } \\
\text { as reader, writer, and } \\
\text { mathematician }\end{array}$ \\
\hline $\begin{array}{l}\text { Early } \\
\text { adolescence } \\
\text { (Age 13-14) } \\
\text { (Cont'd) }\end{array}$ & $\begin{array}{l}\text { Learning to me means } \\
\text { to find new things, } \\
\text { new understandings of } \\
\text { things, ask questions } \\
\text { about what is around } \\
\text { you and so forth. You } \\
\text { start to know new } \\
\text { things that you haven't } \\
\text { known before. You } \\
\text { can learn from any- } \\
\text { thing. Well, much of } \\
\text { anything. Life itself } \\
\text { provides a huge learn- } \\
\text { ing opportunity. }\end{array}$ & & $\begin{array}{l}\text { Creating an environment for } \\
\text { the reader to see.... It can also } \\
\text { be started as a basis of your } \\
\text { own feelings. It can be based } \\
\text { on real things that happened } \\
\text { in your life. Writing is a way } \\
\text { how to describe your feelings } \\
\text { or how you felt at the time. } \\
\text { Like if you're writing like a } \\
\text { story or something. Or if you're } \\
\text { writing about someone you } \\
\text { can like describe why they're } \\
\text { important to you or like why } \\
\text { does it seem so important that } \\
\text { that happened. Cause you } \\
\text { know most people want to } \\
\text { read what they feel is good to } \\
\text { read or fun to read. }\end{array}$ & & $\begin{array}{l}\text { "You have to read this } \\
\text { book, it's great." I want to } \\
\text { show you that life is not as } \\
\text { it seems. I want to make } \\
\text { people want to change the } \\
\text { world for the better. I want } \\
\text { to make a difference. }\end{array}$ \\
\hline $\begin{array}{l}\text { Mid- } \\
\text { adolescence } \\
\text { (Age 15-16) }\end{array}$ & $\begin{array}{l}\text { Ideas about learning } \\
\text { and self-as-learner are } \\
\text { combined with ideas } \\
\text { about the nature of } \\
\text { knowledge. } \\
\text { Finding our something } \\
\text { new that you're inter- } \\
\text { ested in, and feel that } \\
\text { you need to know for } \\
\text { yourself rather than } \\
\text { just by being fed. If } \\
\text { you just fed this infor- } \\
\text { mation it's not useful } \\
\text { to you, you just have it } \\
\text { and most of the time } \\
\text { you won't retain it, but } \\
\text { if you have a passion } \\
\text { for it, then you are } \\
\text { really learning some- } \\
\text { thing. There's a spark } \\
\text { l'd say ... like when } \\
\text { you are happy with } \\
\text { what you doing.... }\end{array}$ & $\begin{array}{l}\text { Personal beliefs about reading } \\
\text { (sharing an author's/character's } \\
\text { world; considering similarities and } \\
\text { differences to one's own expe- } \\
\text { riences, values, and beliefs) are } \\
\text { combined with ideas about their } \\
\text { own development in light of know- } \\
\text { ledge gained through reading. } \\
\text { It's someone else teaching you, } \\
\text { through the process of them writ- } \\
\text { ing. It's like time displacement - } \\
\text { you read it and you absorb that } \\
\text { information. You are getting more } \\
\text { information. It can change your } \\
\text { emotion, and changes your like } \\
\text { outlook on things; it might change } \\
\text { your opinion. }\end{array}$ & $\begin{array}{l}\text { Ideas about writing as process } \\
\text { and understandings of the } \\
\text { nature of knowledge dissemi- } \\
\text { nation and communication are } \\
\text { combined to demonstrate } \\
\text { understanding of writing as } \\
\text { interactive communication. } \\
\text { It's basically another form of } \\
\text { communication you write to } \\
\text { someone else to see if ... } \\
\text { another form of communica- } \\
\text { tion, like reading except it's a } \\
\text { bit more personal because if } \\
\text { you are the one who's writing } \\
\text { to someone else then that } \\
\text { other person receives your } \\
\text { thoughts and feelings ... whe- } \\
\text { reas in a book you read } \\
\text { someone else's. }\end{array}$ & $\begin{array}{l}\text { Beliefs about the usefulness of } \\
\text { math, their engagement with it, and } \\
\text { their attitudes are combined with } \\
\text { their understanding of the nature of } \\
\text { mathematics. } \\
\text { Math is reasoning in a really con- } \\
\text { crete manner. It's not like } \\
\text { imagination; it's just more like really } \\
\text { trying to get straight to the point so } \\
\text { you're trying to always seek some- } \\
\text { thing and there's like an absolute } \\
\text { value you are trying to find. }\end{array}$ & $\begin{array}{l}\text { Writing ... I have so much } \\
\text { of it at home that I knew } \\
\text { that I could just choose } \\
\text { something and bring it } \\
\text { here to read to you. And it } \\
\text { kind of shows just me and } \\
\text { it's the best way that I felt } \\
\text { that I could show who I } \\
\text { am, I guess. I'm looking } \\
\text { back at this now and it's } \\
\text { absolutely horrible be- } \\
\text { cause there's so many } \\
\text { things that I have to fix in } \\
\text { it, but I mean this is just } \\
\text { the first, first draft, like I } \\
\text { haven't fixed anything at all } \\
\text { and I thought that was the } \\
\text { best thing to bring in be- } \\
\text { cause if you bring } \\
\text { something in that you've } \\
\text { already looked over and } \\
\text { fixed and everything, it's } \\
\text { the finished product, it's } \\
\text { not exactly who I am. }\end{array}$ \\
\hline
\end{tabular}


awareness of self as learner in middle childhood. In early adolescence, self-awareness was linked to awareness of knowledge traditions, and learning was viewed as transformative. By midadolescence, knowledge of self-as-learner was linked to ideas about the nature of knowledge. A similar developmental pattern in the interview data was evident with more variability apparent among older students (Table 2). As children mature and have a more extensive 'developmental repertoire' of conceptual understandings, the ways in which they express these understandings varies accordingly (Case, 1985). Levels of understanding among the adolescents were distributed across several levels of understanding, whereas younger students' distributions tended to cluster predominantly at one or two levels.

Table 2

Developmental Pattern in Interview Data

\begin{tabular}{|c|c|c|c|c|}
\hline \multirow[t]{2}{*}{ Nature of response } & \multicolumn{4}{|c|}{ Grade } \\
\hline & $\begin{array}{c}1 \\
(n=2)\end{array}$ & $\begin{array}{l}3 \text { and } 5 \\
(n=14)\end{array}$ & $\begin{array}{l}6 \text { and } 7 \\
(n=12)\end{array}$ & $\begin{array}{c}10 \text { and } 12 \\
(n=11)\end{array}$ \\
\hline Action-based (early childhood) & $100 \%$ & $7 \%$ & $0 \%$ & $0 \%$ \\
\hline Action coordinated with mental activity (ages 8-10) & $0 \%$ & $43 \%$ & $25 \%$ & $18 \%$ \\
\hline Multiple ways of engaging in mental activity (ages 11-12) & $0 \%$ & $43 \%$ & $58 \%$ & $36 \%$ \\
\hline Link to knowledge traditions (ages 13-14) & $0 \%$ & $7 \%$ & $17 \%$ & $28 \%$ \\
\hline Ideas about the nature of knowledge (ages 15-16) & $0 \%$ & $0 \%$ & $0 \%$ & $18 \%$ \\
\hline
\end{tabular}

\section{Representations}

The representations highlight the many different ways children think about their own abilities and the richness of expression facilitated by offering choice in the medium of representation. Nineteen participants chose to represent an identity additional to those of reader, writer, and mathematician; among these were five artists, one fashion designer, three musicians, three athletes, one dancer, two scientists, one gamer, one pet owner, one lover of expensive jewelry, and one who expressed multiple identities (example follows). Six other participants identified themselves as passionate writers and thus did not choose an additional identity. The characteristics of the representations mirror the developmental progression described in Table 1 but demonstrate additional dimensions and bring to light the passion to learn. A first grader, Ethan, for example, represented his identities as reader and artist in an action-filled drawing.

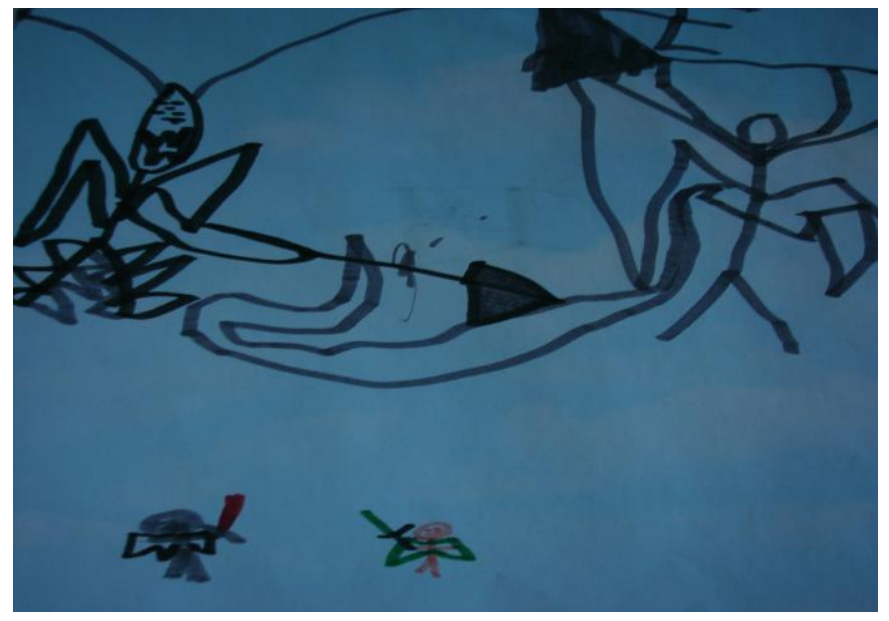

I like reading. I love it! I'm reading a chapter book about Star Wars. That's the master...fighting the master... evil ...he fights the hardest guys to beat. Like the flying armored ones with huge wings. The wings are as big as the school. I like to draw lots. Draw and read. I like reading more. 

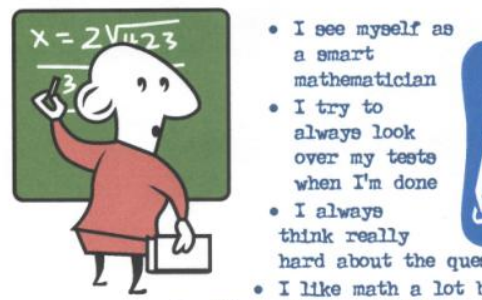

- I alwaye

hard about the questions

- I like math a lot because I like to

work with numbers and I ltke adding and dotng multiplication

- I am good at both my basic facto and advanced facto

- At gchool we go on math webettee and I find them really intereating and cool
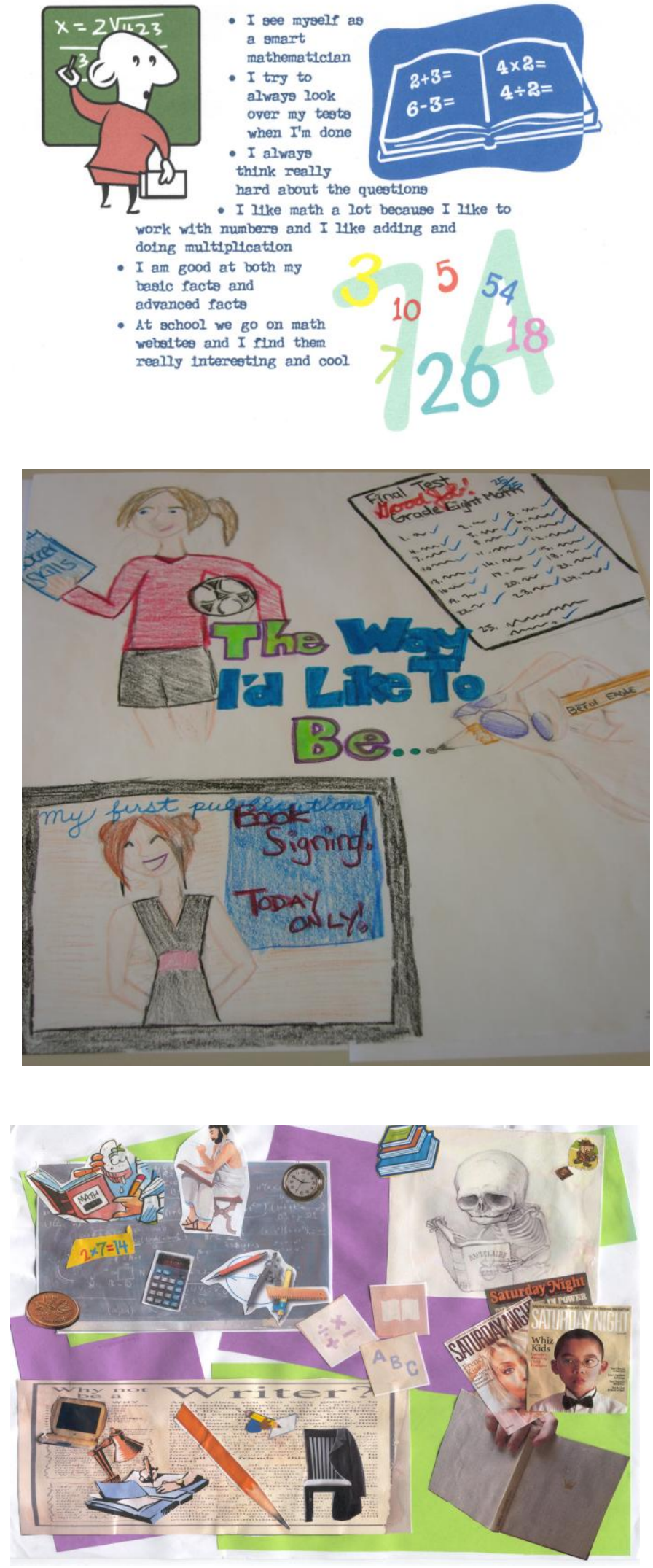

Lyle, in Grade 3, wrote and used computer graphics to represent his thinking about himself as a mathematician, showing his understanding of the role of mental activity and different ways of learning.

Sara, in Grade 7, demonstrated a wellarticulated, coherent sense of herself as reader, writer, mathematician, and athlete in her drawing as well as indicating her awareness of the future in her depiction of herself at her first book signing.

Melanie, also in Grade 7, demonstrated the more sophisticated understanding of early adolescence in her representations of the knowledge tradition in mathematics and the variety of sources of learning and learning tools. 
Chris, in Grade 12, demonstrated the links between learning, self-as-learner, and ideas about knowledge in the following response containing his list of ideas about himself as a writer.

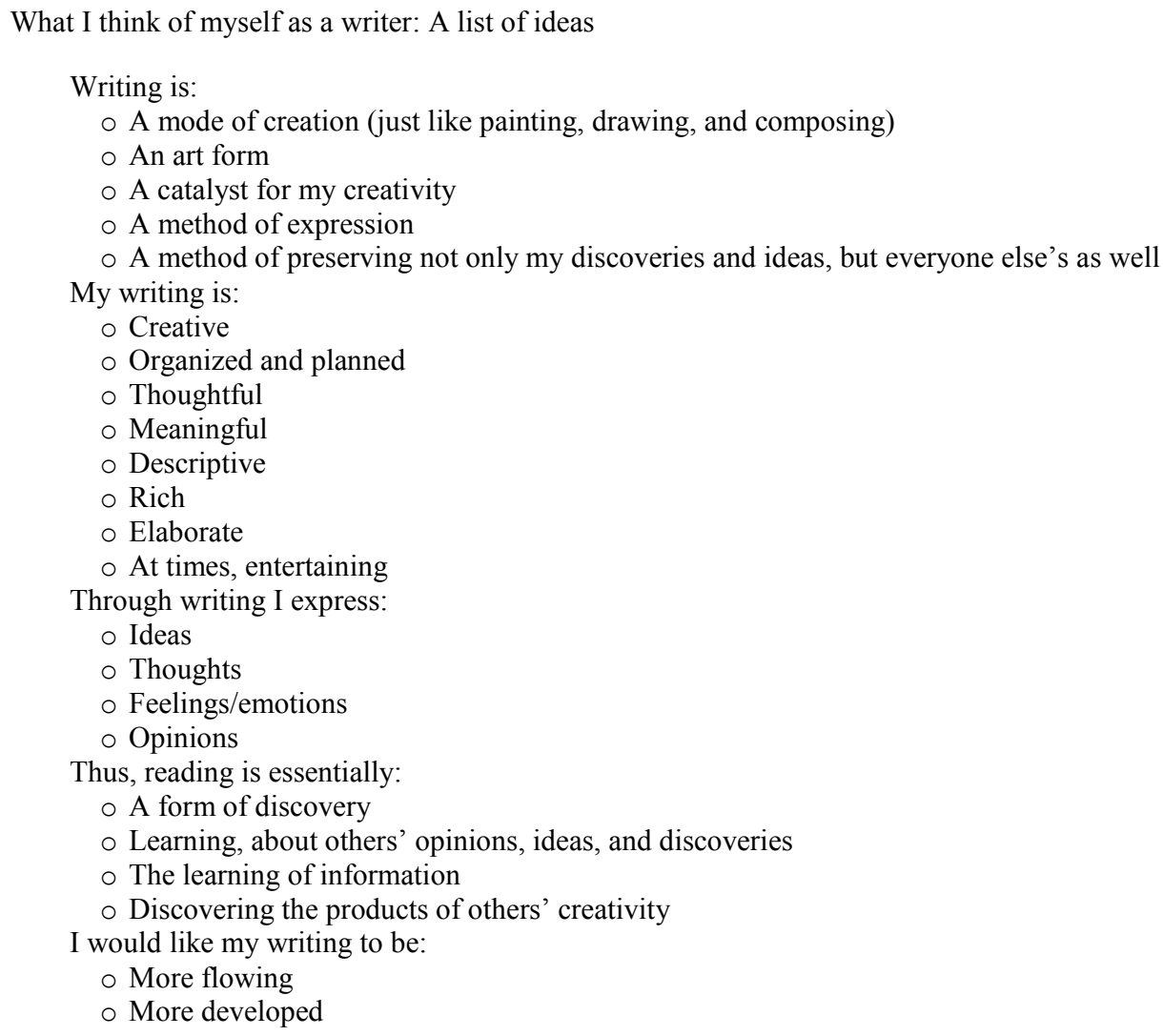

Beyond a developmental trajectory. Leaving aside the question of how development appears to influence the content, structure, and meaning of representations, it is clear that representations, in whatever form, shine a complementary light on students' perspectives of their learning identities. What follows is a selection of representations to be viewed, read, and listened to for what else they tell us about learning identities. This selection is intended to evoke further thought about what children reveal about their ways of learning and the nuances of their experiences (Eisner, 2008), to present "new ways with which to perceive and interpret the world, ways that make vivid realities that would otherwise go unknown" (Eisner, 2008, p. 11).

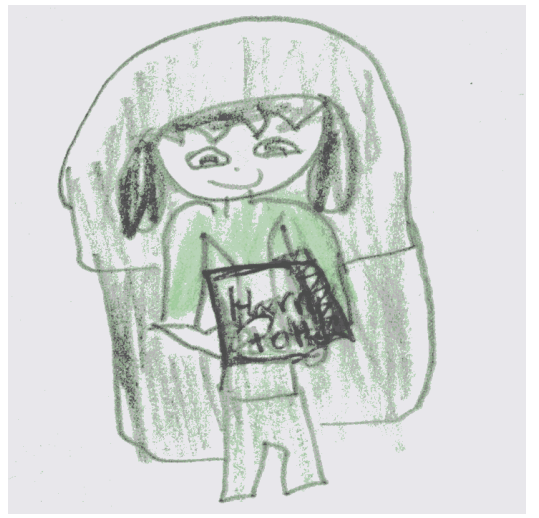

Jessica, Grade 4

How I Would Like to Show Myself as a Writer 


\author{
Diamante \\ Speed - \\ Explosive, Power \\ Emotionless, Freezing, Destructed \\ Furious, Uncontrolled - Calmingly Reserved \\ Graceful, Patiently, Synchronized \\ Rhythmic, Weak \\ Largo
}

Dylan, Grade 7

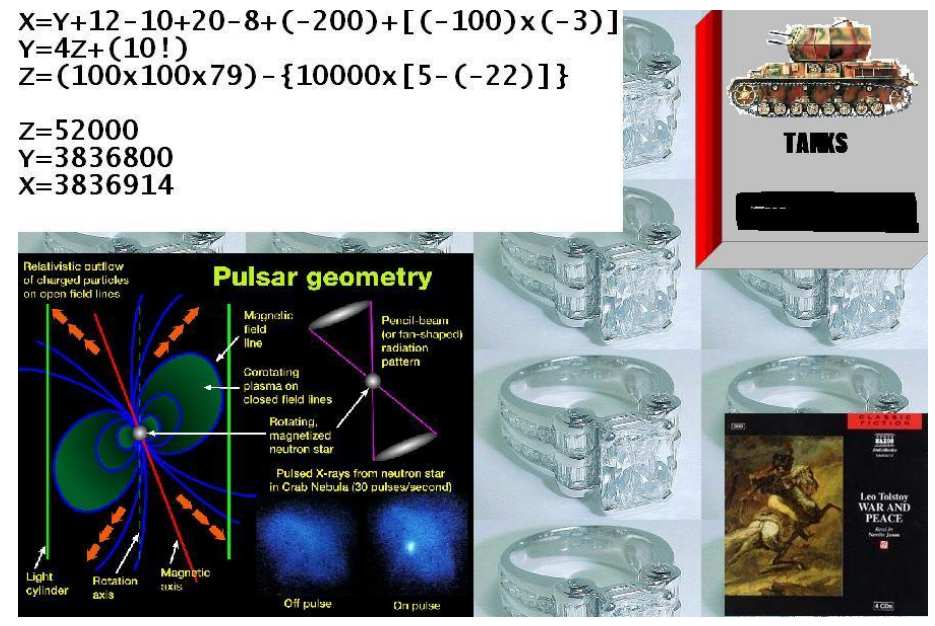

I would like to explain my image. First, the diamond and platinum rings in the background represent my passion for expensive jewelry. Second, the complex algebra problem and the picture of quasar star geometry represent my passion for mathematics and advancing my skill in it in my free time. Third, the item that looks marginally like a book and says "TANKS" is representing my immense liking towards writing non-fiction pieces. Fourth, and finally, the picture in the lower right-hand corner of Leo Tolstoy's famous War and Peace represents my huge will to read. However, feel free to interpret the image as you wish.

Rob, Grade 7

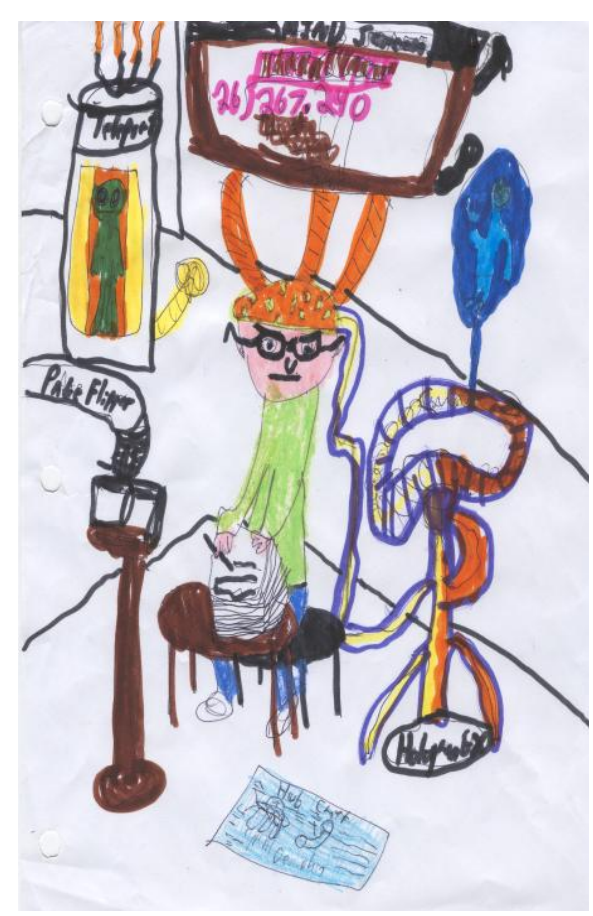

For the optional one, I did scientist. And for that, there was the hovercraft blueprint and it's shaped like a UFO, the top part, and there's kites going down the sides and the top end sucks in air and the bottom end blows it out, which makes the thing float. And to help it, there's a fan in the middle to push down some more air and the hologram machine, it's hooked up to this helmet. It can be hooked up to another things but this helmet has a good power source, and so that's the main power source and it goes up into here and goes through one pipe and this other one is a type of energy and it goes up the other pipe through here and when they meet, they create a message thing, like a screen sort of, it's sort of like a tv, except people can send messages. And the mind screen, it also is for math, it shows me thinking about a math problem, a really hard math problem, and these things are working out the problem and that's the problem.

And this, the helmet, each of these little dots is attached to your head so it probes the brain and gets the ideas and puts them on the screen. And the page flipper, its claw is built like a human hand so that it can bend like a human hand does, so it can grab the page and flip it without you flipping it, instead it does. And the teleporter works, but this powers the thing, the electricity, and there's these four waves and somewhere else, there's another booth like this and it has four waves and the person in there, in this case it was an alien, they press a button and their atoms get dematerialized so that their atoms are still there, but they're sort of apart. And then they get sucked up and go through these and get transformed into a type of energy through these four waves. And then it goes up to a satellite and then the satellite beams it to the place they want it to go to, another satellite, then that beams down to the four wires on this teleport and then the atoms come together in there and then they're there.

It [also] shows me as a reader because I'm reading a book and at the same time, I'm writing a big story. And I'm doing math in my mind, so I'm triple tasking. And as a scientist, I build these things and I discovered the way to make them work and I built things that could enhance people's knowledge and how they get around.

Sam, Grade 5

The helmet, when it probes your brain, it doesn't just go to anywhere because it could show a pony when you wanted it to show a math problem, so they have to be engineered right so that they go to a certain part of the brain and read that so that they don't mess up everything. Yeah, that's it. 
I am a reader because I enjoy reading

I do it because I want to

I am a writer because I love to write

I do it because I want to

I am a mathematician because I like math

I do it because I want to

I am a soccer player because I like to play soccer

I do it because I want to

I am a scientist because I love science

I do it because I want to

I am myself because I am different and unique

I know who I am even if I don't know who I will be

I am not better than anyone else

They are just the same as me

I am a reader, a writer, a mathematician, an athlete, a scientist, myself

Not because I have to but because I choose to

Jill, Grade 6

Numbers crunching, pencil in flurry calculator, ruler, compass, protractor pi, eternity, computations, break through problems, logic, success.

Telling stories, expressing emotion sharing gifts, exploring, english language mental gymnastics, deadlines, time passion, engaging, stimulating, fun.

Seeing new worlds, exploring ideas

Making sense of language, expressions, thoughts

Characters, settings, plot, story, literature.

Worlds only a page away.

Lab, hive of activity, experiments

Tests, creations, hypothesis, chemicals,

Creatures, beakers, test tubes, making

Life, playing God, creation.

Graham, Grade 7

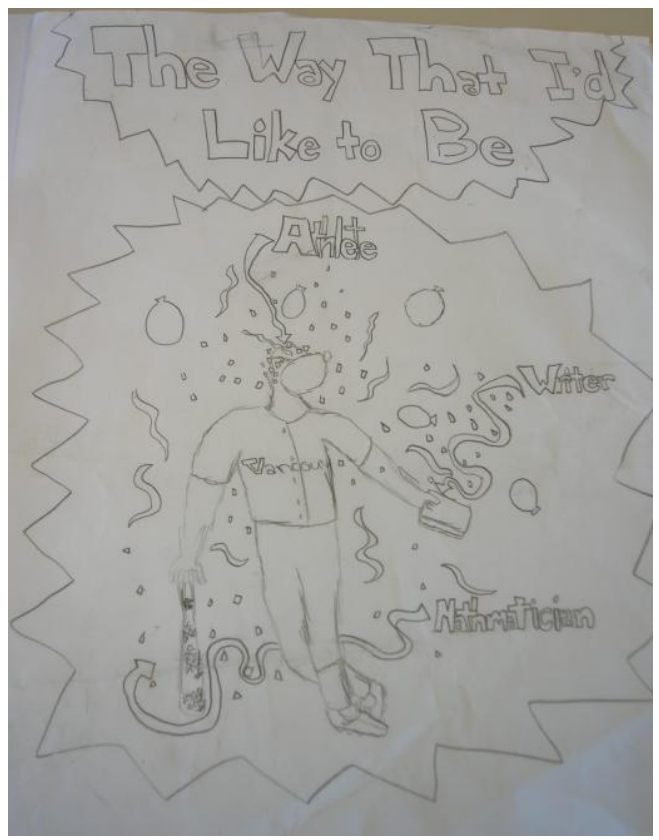

Sam, Grade 7 
I have an extra. I wanted to represent myself as a musician.

It's a very nice lyrical piece. I chose that piece because I like lyrical pieces very much and it's a very emotional piece so I just think it's a very good example of music.

Leon, Grade 7

\section{Discussion}

Mental representations are indeed a powerful tool for achieving greater understanding of the ways in which gifted learners develop and how they view their learning. They allow us a perspective on children's learning identities that conventional ways of representing knowledge do not; they allow for "rethinking the languages of learning" (Gallas, 1994, p. 148). The multiple representations produced highlight the many different ways children think about their own abilities and the richness of expression facilitated by offering choice in the medium of representation. Through both their talk and their representations, a portrait of development of gifted learners' increasingly complex notions of learning and learning identities was painted.

The principle underpinning this research takes children's understandings of learning and the curriculum as necessary starting points for pedagogy. Children's understandings are rarely engaged in this way, but when they are, the result for children is deeper and more meaningful learning (Donovan, Bransford, \& Pellegrino, 1999; Fosnot, 1996; Griffin \& Case, 1996). This sort of engagement is imperative in meeting the diverse educational needs in today's classrooms (Gould, 1996). Further, because our knowledge of issues pertinent to children is largely "proxy information" gathered by researchers but unconfirmed by children themselves, the researcher's way of "seeing children" is critical in eliciting valid and useful information (Morrow \& Richards, 1996), as is the educator's.

Children's efforts to articulate and represent their feelings, understandings, and theories about education belong to them (Huxtable, 2009); as such, children need to be afforded an appropriate range of opportunities to help them develop their theories. Children's efforts, and similar efforts on the part of their teachers, to understand learning in a deep and meaningful way are believed to be critical in moving gifted education practices forward (Huxtable, 2009). An important aspect of this movement forward is that engagement of children in their own learning gives educators a window on 'gift-creation' (Hymer, 2009) rather than identification. Encouraging multiple ways of representing learning identities allows educators to recognize and develop many forms of emergent gifts and understand what matters to children.

Our "learning society" (Keating \& Hertzman, 1999) emphasizes deep understanding and application of knowledge. Understanding the developmental trajectory of perspectives on knowledge, self-as-learner, and self-as-academic is important both for informing our conversations with students about learning and academic progress and for scaffolding their development to deeper understandings. Knowing how students conceptualize their learner identities and how understanding develops from simple to complex provides a 'design for development' for educators to scaffold deep understanding of learner identities (McKeough, Okamoto, \& Porath, 2002; Porath, 2006) by engaging students in discussions that will lead to higher level thinking about learning and knowledge. For example, young children can be encouraged to name and discuss mental activity and students who show an understanding of the multiple ways of engaging in mental activity can begin to engage in discussions of how learning is transformative. Similarly, 
understanding what other identities are important to them allows educators a more complex view of students, one that considers academic achievement in a holistic context. Students' representations of what makes them feel competent may help them to increase understanding of what defines them as competent, thus affirming their abilities to themselves, their teachers, and their communities (Delpit, 2003).

\section{Directions for Research}

The present study focused on students identified as gifted to address our lack of knowledge of gifted students' perspectives on their own learning. Its objective was to give students sufficient scope to provide creative and insightful views of educational endeavors that are important to them and their learning identities. As such, the study provides a foundation for further exploration of all students' learning identities via multiple representations.

Access to multiple representations of learning material provided by teachers or curriculum developers positively influences learning (Eilam \& Poyas, 2008) and may enhance motivation, although that hypothesis requires further study (Eilam \& Poyas, 2008). The effect on learning and motivation when students are involved in creating their own representations is also an interesting avenue for further study. Because children's mental representations can be "carriers of socialization" (Dweck \& London, 2004, p. 429), they also may offer us insight into the impact of educational conversations and strategies.

Opportunities for children to represent their knowledge in a number of ways can also serve as "provocations" for children's ideas (Malaguzzi, 1993; Rodari, 1973), encouraging them to ask questions of each other and engage in "conceptual translation" (Gardner, 2001) of their knowledge from one mode to another. Detailed documentation of this conceptual translation and the influence of different modes on it are other avenues for further research.

\section{References}

Bickerton, G. (1994, June). Narrative knowledge as revealed in children's perceptions of learning. Paper presented at the Canadian Society for the Study of Education, The University of Calgary.

Bransford, J. D., Brown, A. L., \& Cocking, R. C. (Eds.). (2000). How people learn: Brain, mind, experience, and school. Washington, DC: National Academy Press.

Bruner, J. (1986). Actual minds, possible worlds. Cambridge, MA: Harvard University Press.

Bruner, J. (1996). The culture of education. Cambridge, MA: Harvard University Press.

Case, R. (1985). Intellectual development: Birth to adulthood. New York: Academic Press.

Case, R. (1992). The mind's staircase: Exploring the conceptual underpinnings of children's thought and knowledge. Hillsdale, NJ: Erlbaum.

Delpit, L. (2003). Educators as "seed people" growing a new future. Educational Researcher, 17(32), 1421.

Donovan, M. S., Bransford, J. D., \& Pellegrino, J. W. (Eds.). (1999). How people learn. Bridging research and practice. Washington, DC: National Academy Press.

Dweck, C. S., \& London, B. (2004). The role of mental representation in social development. MerrillPalmer Quarterly, 50, 428-444.

Eilam, B., \& Poyas, Y. (2008). Learning with multiple representations: Extending multimedia learning beyond the lab. Learning and Instruction, 18, 368-378.

Eisner, E. (2008). Art and knowledge. In J. G. Knowles \& A. L. Cole (Eds.), Handbook of the arts in qualitative research (pp. 3-12). Los Angeles: Sage. 
Fosnot, C. T. (Ed.). (1996). Constructivism. Theory, perspectives, and practice. New York: Teachers College Press.

Gallas, K. (1994). The languages of learning: How children talk, write, dance, draw, and sing their understanding of the world. New York: Teachers College Press.

Gardner, H. (2001). Introductions. In Project Zero (Harvard University) \& Reggio Children. Making learning visible: Children as individual and group learners (pp. 25-27). Reggio Emilia, Italy: Reggio Children.

Gould, J. S. (1996). A constructivist perspective on teaching and learning in the language arts. In C. T. Fosnot (Ed.), Constructivism. Theory, perspectives, and practice (pp. 92-102). New York: Teachers College Press.

Griffin, S., \& Case, R. (1996). Evaluating the breadth and depth of training effects when central conceptual structures are taught. In R. Case \& Y. Okamoto (Eds.), The role of central conceptual structures in the development of children's thought (pp. 83-102). Monographs of the Society for Research in Child Development, 61(1-2, Serial No. 246).

Hanna, J. L. (2008). A nonverbal language for imagining and learning: Dance education in K-12 curriculum. Educational Researcher, 37, 491-506.

Henwood, K., \& Pidgeon, N. (2003). Grounded theory in psychological research. In P. M. Camic, J. E. Rhodes, \& L. Yardley (Eds.), Qualitative research in psychology: Expanding perspectives in methodology and design (pp. 131-155). Washington, DC: American Psychological Society.

Huxtable, M. (2009). Creating inclusive and inclusional understandings of gifts and talents through living educational theory research. In T. Balchin, B. Hymer, \& D. J. Matthews (Eds.), The Routledge international companion to gifted education (pp. 292-298). London: Routledge.

Hymer, B. J. (2009). Beyond compare? Thoughts towards an inclusional, fluid and non-normative understanding of giftedness. In T. Balchin, B. Hymer, \& D. J. Matthews (Eds.), The Routledge international companion to gifted education (pp. 299-307). London: Routledge.

Katz, L. G. (1998). What can we learn from Reggio Emilia? In C. Edwards, L. Gandini, \& G. Forman (Eds.), The hundred languages of children: The Reggio Emilia approach - Advanced reflections (2nd ed., pp. 27-45). Greenwich, CN: Ablex.

Keating, D. P. (1991). Curriculum options for the developmentally advanced: A developmental alternative to gifted education. Exceptionality Education Canada, 1(1), 53-83.

Keating, D. P., \& Hertzman, C. (Eds.). (1999). Developmental health and the wealth of nations. New York: The Guilford Press.

Krechevsky, M., \& Seidel, S. (1998). Minds at work: Applying multiple intelligences in the classroom. In R. J. Sternberg \& W. M. Williams (Eds.), Intelligence, instruction, and assessment: Theory into practice (pp. 17-42). Mahwah, NJ: Erlbaum.

Liddle, E., \& Porath, M. (2002). Gifted children with written output difficulties: Paradox or paradigm. Australian Journal of Learning Disabilities, 7, 13-19.

Lubinski, D., \& Benbow, C. P. (2000). States of excellence. American Psychologist, 55, 137-150.

Malaguzzi, L. (1993). History, ideas, and basic philosophy. In C. Edwards, L. Gandini, \& G. Forman (Eds.), The hundred languages of children: The Reggio Emilia approach to early childhood education (pp. 41-89). Norwood, NJ: Ablex.

Matthews, D. J. (1997). Diversity in domains of development: Research findings and their implications for gifted identification and programming. Roeper Review, 19, 172-177.

McKeough, A., Okamoto, Y., \& Porath, M. (2002, April). A design for development: The legacy of Robbie Case. Sylvia Scribner lecture, American Educational Research Association, New Orleans.

Morrow, V., \& Richards, M. (1996). The ethics of social research with children: An overview. Children \& Society, 10, 90-105.

Perry, T. (2003). Up from the parched earth: Toward a theory of African-American achievement. In T. Perry, C. Steele, \& A. Hilliard, III (Eds.), Young, gifted and Black: Promoting high achievement among African American students (pp. 1-108). Boston: Beacon. 
Porath, M. (2006). The conceptual underpinnings of giftedness: Developmental and educational implications. High Ability Studies, 17, 145-157.

Porath, M., \& Lupart, J. (2007, May). The child as psychologist: Gifted students making meaning of learning and knowledge. Paper presented at the Canadian Society for the Study of Education, University of Saskatchewan.

Project Zero (Harvard University) \& Reggio Children. (2001). Making learning visible: Children as individual and group learners. Reggio Emilia, Italy: Reggio Children.

Robinson, N. M., Zigler, E., \& Gallagher, J. J. (2000). Two tails of the normal curve: Similarities and differences in the study of mental retardation and giftedness. American Psychologist, 55, 1413-1424.

Rodari, G. (1973). Grammatica della fantasia. Torino, Italy: Einaudi.

Root-Bernstein, M., \& Root-Bernstein, R. (2005). Body thinking beyond dance. In L. Y. Overby \& B. Lepczyk (Eds.), Dance: Current selected research: Vol. 5. Dance education (pp. 173-201). New York: AMS Press.

Waksler, F. C. (1991). Studying children: Phenomenological insights. In F. C. Waksler (Ed.), Studying the social worlds of children: Sociological readings (pp. 60-69). London: The Falmer Press.

Woo, Y. Y. J. (2008). Engaging new audiences: Translating research into popular media. Educational Researcher, 37, 321-329.

Yewchuk, C., \& Lupart, J. (2000). Inclusive education for gifted students with disabilities. In K. Heller, F. Monks, R. Sternberg, \& R. Subotnik (Eds.), International handbook of giftedness and talent (2nd ed., pp. 659-670). Amsterdam: Elsevier.

\section{Authors' Note}

Correspondence concerning this article should be addressed to Dr. Marion Porath, Faculty of Education, UBC, 2125 Main Mall, Vancouver, BC V6T 1Z4. Email: marion.porath@ubc.ca.

This research was supported by the Social Sciences and Humanities Research Council of Canada. A version of this paper was presented at the Canadian Society for the Study of Education, The University of British Columbia, June, 2008. 


\section{Appendix}

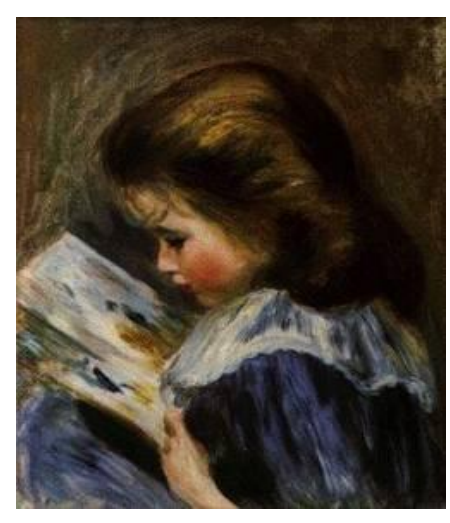

Choose a way of showing yourself as a reader the way you'd like to be.

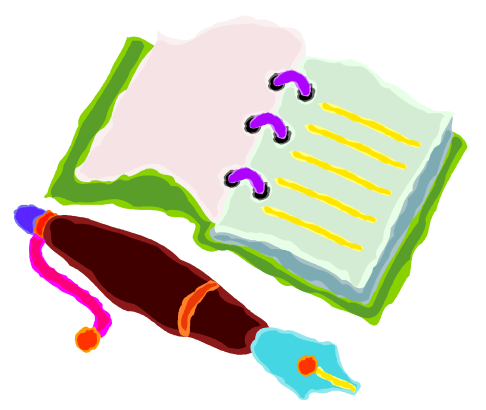

Choose a way of showing yourself as a writer the way you'd like to be.

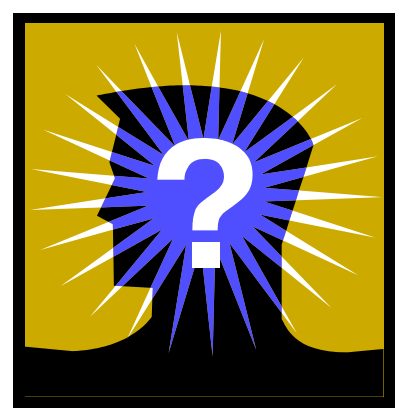

Choose a way of showing yourself as a mathematician the way you'd like to be.

Optional. Choose a way of showing yourself as a the way you'd like to be. 